\title{
Relative Contribution of Various Sources of Botrytis cinerea Inoculum in Strawberry Fields in Norway
}

Gunn Mari Strømeng, Norwegian University of Life Sciences, Department of Chemistry, Biotechnology and Food Science, and Norwegian Institute for Agricultural and Environmental Research, Plant Health and Plant Protection Division; Linda Gordon Hjeljord, Norwegian University of Life Sciences, Department of Chemistry, Biotechnology and Food Science; and Arne Stensvand, Norwegian Institute for Agricultural and Environmental Research, Plant Health and Plant Protection Division, N-1432 Ås, Norway

\begin{abstract}
Strømeng, G. M., Hjeljord, L. G., and Stensvand, A. 2009. Relative contribution of various sources of Botrytis cinerea inoculum in strawberry fields in Norway. Plant Dis. 93:1305-1310.

To identify the most important sources of inoculum of Botrytis cinerea (causal agent of gray mold) in commercial strawberry (Fragaria $\times$ ananassa) fields in Norway, soil and overwintered plant material were collected from planting beds and alleys at five locations in 2000 to 2002 (13 samples altogether). Plant material was sorted by category (e.g., leaves, stems, mulch, and weeds). After subsamples of each material were incubated for 5 days at $20^{\circ} \mathrm{C}$ at high humidity, conidiophores of $B$. cinerea growing from mycelia and sclerotia were counted. Overwintered plant debris within planting beds yielded more than $96 \%$ of total conidiophores counted, the remainder originating from plant debris collected from alleys or soil. Overwintered strawberry plant debris produced $98 \%$ of the conidiophores within planting beds and $80 \%$ of the conidiophores in the alleys, while the remaining was produced by weeds. Senescing and dead leaf laminae produced $45 \%$ of the conidiophores while stem residues (i.e., petioles, stolons, inflorescences, and unidentifiable stem parts) produced $50 \%$ and mummified fruit produced $5 \%$ within planting beds. The contribution of sclerotia, compared with mycelia, to conidiophore production varied greatly between fields and years. Overall, $47 \%$ of the total number of conidiophores produced in plant material within planting beds originated from sclerotia. More than $90 \%$ of the conidiophores from sclerotia were found in dead stem residues.
\end{abstract}

Botrytis fruit rot (gray mold), caused by the fungal pathogen Botrytis cinerea Pers., is responsible for severe yield losses in strawberry (Fragaria $\times$ ananassa) worldwide, and is the most important disease in field-grown strawberry in Norway. Because symptoms on fruit commonly originate from latent infections initiated by conidia in the flowers $(10,15)$, control is based on two to five fungicide applications during flowering. Both strawberry flowers and unripened berries are present in the field during treatment, and therefore fungicide residues are frequently detected on harvested fruit. In a European pesticide residue report in $2004,63 \%$ of the strawberry samples contained pesticide residues and $2.8 \%$ of these samples exceeded the maximum residue limit (6). The most frequently detected substances, cyprodinil, fenhexamid, and tolylfluanid (detected in $33.9,22.4$, and $20.6 \%$ of the samples, respectively), are all used to control $B$. cinerea. Identification of sources of $B$. cinerea

Corresponding author: A. Stensvand

E-mail: arne.stensvand@bioforsk.no

Accepted for publication 30 July 2009.

doi:10.1094/PDIS-93-12-1305

(C) 2009 The American Phytopathological Society inoculum produced in the spring might facilitate efforts to reduce inoculum during flowering and reduce the amount of fungicides applied, as was demonstrated in Ontario, Canada (1), and in the United Kingdom (12).

$B$. cinerea can overwinter as mycelium in dead or living plant material or as sclerotia on plant debris, on the soil surface, or buried in soil $(2-4,10)$. Mycelia and sclerotia produce conidiophores and conidia in spring. Although sclerotia may also germinate to produce apothecia and ascospores of Botryotinia fuckeliana (de Bary) Whetzel, the sexual stage of Botrytis cinerea (7), the role of the teleomorph in the epidemiology of disease caused by the fungus is unclear and, to our knowledge, Botryotinia fuckeliana has not been reported in strawberry fields.

In Ontario, mycelia in dead strawberry leaf laminae and leaf petioles contributed more than $90 \%$ of the conidial inoculum in the spring (2). In Scotland, strawberry plant debris, weeds, and straw all were reported to be inoculum sources of Botrytis cinerea in spring (10) but the relative importance of the different substrates for conidia production was not determined. Previous reports on strawberry and other crops indicated that the relative importance of sclerotia of $B$. cinerea as inoculum source varies. For example, sclerotia con- tributed less than $8 \%$ of the conidial inoculum in strawberry fields in Ontario (2). In Scotland, however, sclerotia were considered important in overwintering of the fungus (10); viable sclerotia were present in $35 \%$ of dead petioles and stolons, $70 \%$ of inflorescences and peduncles, $50 \%$ of the straw fragments, and all mummified fruit. In that study, however, the importance of sclerotia in conidial production was not determined.

The relative contribution of various sources of overwintering inoculum to gray mold epidemics in strawberry under Nordic conditions has not been precisely quantified. Efforts to reduce spring inoculum might be improved if those targets of greatest importance to epidemic progress could be identified. Our aim, therefore, was to identify substrates for conidia production by $B$. cinerea in strawberry fields in Norway and to quantify their relative importance as sources of inoculum. Preliminary results of this study have been published (17).

\section{MATERIALS AND METHODS}

Experimental design. Plant material and soil were collected in strawberry fields during spring of 2000, 2001, and 2002 at each of five locations in five different counties in southern Norway: Eina in Oppland, Kvelde in Vestfold, Marnardal in Vest-Agder, Idse in Rogaland, and Valldal in Møre og Romsdal (Fig. 1). Altogether, there were 13 separate collections. In 2000, material was collected approximately 2 weeks before flowering whereas, in 2001 and 2002, material was collected 3 to 4 weeks before flowering, when new growth appeared. Cropping systems, cultivars, crop age, and collection dates for each site are shown in Table 1.

Each collection was treated as a replicate or experimental unit. Plant material and soil were collected within a 30-by-30-m area at each site. A $25-\mathrm{cm}$-square metal frame was thrown randomly five times onto the planting rows and five times into the alleys within the collection area. All aboveground plant material within a frame was collected, as was $200 \mathrm{ml}$ of soil from the surface. From plastic-mulched planting beds, soil was collected only from areas of exposed soil in the immediate vicinity of the plants. The five within-row and within- 
alley collections of plant material were pooled into separate samples. The 10 within-row and within-alley collections of soil samples were pooled into a single sample. Thus, there was a within-row sample of plant material, a within-alley sample of plant material, and a single 2-liter composite soil sample from each site on each collection date.

Processing of plant and soil samples. The plant material in each sample was sorted into different categories: senescing (partly necrotic) and dead leaf laminae, senescent and dead petioles, dead stolons, dead inflorescences, mummified fruit, weeds, and straw. The surface area of the material in each category (except straw mulch within alleys) was measured using a leaf area meter (Li-Cor 3100; Li-Cor, Lincoln, NE). Then, three random subsamples from each category were collected and the surface areas of these subsamples were measured. In general, each subsample consisted of 10 leaflets, 10 petioles, 10 stolons, or three to five inflorescences, while the subsample size in the other cate-

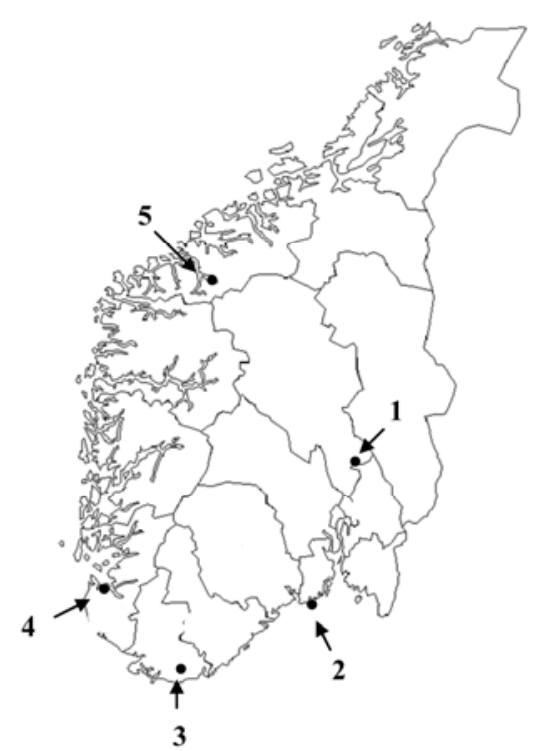

Fig. 1. Collection sites in southern Norway (59 to $64^{\circ} \mathrm{N}$ ) for soil and strawberry plant material samples: 1, Eina, Oppland County; 2, Kvelde, Vestfold County; 3, Marnardal, Vest-Agder County; 4, Idse, Rogaland County; and 5, Valldal, Møre og Romsdal County. gories varied depending upon the amounts in the different fields. The subsamples were placed in small moisture chambers (plastic boxes containing wet paper towels in the bottom) in which the plant material was placed on a metal grid to avoid contact with the paper. The boxes were sealed in plastic bags and incubated at $20^{\circ} \mathrm{C}\left( \pm 2^{\circ} \mathrm{C}\right)$ in darkness for 5 days. These conditions were consistent with those used in a previous study (2). Conidiophores produced in the plant material were quantified as described below.

The soil samples were spread out in thin layers on filter paper in perforated trays and placed at $20^{\circ} \mathrm{C}$ in a drying cabinet with forced air circulation to accelerate the drying process and, thus, avoid germination of sclerotia. After 2 to 3 days, the soil was pressed through a sieve (mesh size, $0.7 \mathrm{~mm}$ ) to break up clods in the soil. The soil was further dried for another 7 to 8 days before dry weights of all soil samples were measured. Dried soil samples were stored in sealed plastic bags at room temperature for up to 4 weeks before incubation and examination. Three subsamples (50 g dry weight) from each soil sample were screened into four categories using sieves of different mesh size $(<0.7 \mathrm{~mm}, 0.7$ to $2 \mathrm{~mm}, 2$ to $3 \mathrm{~mm}$, and $>3 \mathrm{~mm}$ ) to reveal small sclerotia hidden by larger soil particles. To initiate sporulation for detection of sclerotia, the soil subsamples were spread out in thin layers on filter paper in plastic boxes and sprayed with distilled water until the filter paper was evenly moistened. The boxes were sealed in plastic bags and incubated at $20^{\circ} \mathrm{C}\left( \pm 2^{\circ} \mathrm{C}\right)$ in darkness for 5 days.

A dissecting microscope was used to detect conidiophores of $B$. cinerea on incubated plant material and soil. On plant material, conidiophores on the side of the material facing upward during incubation were counted. All conidiophores were counted, except where conidiophores were formed in dense masses. In these instances, they were counted in one portion of the sporulating area and, from this, the total number of conidiophores in the entire sporulating area was estimated. Conidiophores emerging from sclerotia or mycelia were counted separately. Only sporulating sclerotia in the samples were counted, because sclerotia of $B$. cinerea were de- tected and confirmed by the morphology of the conidiophores. In some samples, plant debris of a particular category was not found. In these instances, zero values were assigned to numbers of conidiophores and sclerotia. The numbers of conidiophores and sclerotia counted in the three subsamples of a plant material or soil sample were used in calculating (i) the percentage of conidiophores produced in that sample originating from sclerotia, (ii) the population of conidiophores produced in the entire sample, and (iii) the population of sclerotia in the entire sample. The latter two values were expressed as a number per square meter and based on the total area in the field ( 5 frames for plant material, 10 frames for soil) from which the sample was collected.

Weather data. Temperature, relative humidity, and precipitation measurements for August to May during the years of the study were collected from weather stations (assembled by ITAS, Ås, Norway) at Apelsvoll in Oppland County, Tjølling in Vestfold County, Landvik in Vest-Agder County, Hjelmeland in Rogaland County, and Linge in Møre og Romsdal County. The weather stations were located 10 to 60 $\mathrm{km}$ from the sampled fields.

Analysis of data. Statistical analyses were performed using Minitab 15 statistical software (Minitab Inc.). Analysis of variance was conducted using the GLM procedure, with the experiment being analyzed as a randomized block design. Sample location (i.e., within-row residue, within-alley residue, and soil) and type of plant residue (e.g., leaf laminae, petioles, and inflorescences) were treatment factors while samples (site and year) were blocks. Treatments were compared for conidiophore and sclerotia populations and the percentage of conidiophores originating from sclerotia. In addition, the surface area of each type of strawberry plant part, expressed as a percentage of the total surface area of plant residue, was compared among plant residue types. To meet the assumption of normal distribution, count data were log transformed and percentage data were arcsine square root transformed prior to the analysis; nontransformed data are presented. Tukey's test $(P=0.05)$ was used to separate transformed means.

Table 1. Location, cropping system, cultivar, planting year, and collection dates of soil and plant material

\begin{tabular}{llcc}
\hline Location, county & \multicolumn{1}{c}{ Cropping system } & Cultivar, planting year & Sampling dates \\
\hline Eina, Oppland & Two plant rows on plastic-mulched raised beds; drip irrigation & Korona, 1998 & 23 May 2000, 10 May 2001, \\
& & & 30 April 2002 \\
Kvelde, Vestfold & Two plant rows on plastic-mulched raised beds; sprinkler & Korona, 1998 & 4 May 2000, 23 April 2001 \\
& irrigation; straw mulch between beds & 26 April 2000 & 24 April 2001 \\
Marnardal, Vest-Agder & Two plant rows on plastic-mulched raised beds; drip irrigation & Korona, 1999 & 27 April 2000 \\
& & Korona, 1998 & 27 April 2000, 15 April 2001, \\
Idse, Rogaland & Matted rows; sprinkler irrigation; straw mulch between beds & Honeoye, 1998 & 13 April 2002 \\
& & Korona, 1999 & 9 May 2000 \\
Valldal, Møre og Romsdal & Matted rows on raised beds; sprinkler irrigation & Senga Sengana, 1995 2001 & Polka, 1999 \\
& & & \\
\hline
\end{tabular}


Multiple regression analyses were performed to examine the potential of environmental variables measured from August to November, during the sclerotial formation period, to predict the abundance of sclerotia or the relative contribution of sclerotia to conidiophore production. Predictor variables tested were mean temperature, mean relative humidity, and accumulated precipitation calculated for the entire August-to-November period, for each month separately, and for several of these months combined.

\section{RESULTS}

Potential inoculum in plant material in planting beds, plant material in alleys, and in soil. Potential inoculum production, measured as population of conidiophores, was much higher in plant material from planting beds than material collected from alleys or in soil (Table 2). Conidiophore populations in planting bed debris ranged from 18,700 to 652,400 conidiophores $/ \mathrm{m}^{2}$, with a mean of 137,200 conidiophores $/ \mathrm{m}^{2}$. In contrast, conidiophore populations produced in alley plant debris and in soil samples ranged from 0 to less than 12,000 conidiophores $/ \mathrm{m}^{2}$, and mean conidiophore populations in these two types of material were less than 3,000 conidiophores $/ \mathrm{m}^{2}$.

Importance of different plant parts as inoculum sources. The amounts of plant material collected from planting beds varied considerably among the 13 samples (data not shown), ranging from less than 6,000 $\mathrm{cm}^{2}$ of material $/ \mathrm{m}^{2}$ of planting bed measured in a 1-year-old field (cv. Korona, Rogaland 2000) to more than 31,000 measured in a 4-year-old field (Oppland 2002). Nearly all $(99.8 \%)$ of the plant material collected within planting beds was strawberry plant debris. Weeds and straw each constituted approximately $0.1 \%$. Dead leaf laminae constituted $60 \%$ of the strawberry residue within planting beds (Fig. 2A), which was significantly higher than any other residue category $(P<0.0001)$. Senescing leaf laminae constituted $12 \%$, while all other categories individually made up less than $10 \%$ of the surface area.

Conidiophores were produced in every category of strawberry plant debris collected from planting beds (Fig. 2B). Senescing leaf laminae produced the most $(31 \%)$ while fewer than $15 \%$ of the co- nidiophores were produced in each of the other categories. Although senescing and dead leaf laminae, as a group, constituted $72 \%$ of the total residue surface area measured in planting beds (Fig. 2A), it produced only $45 \%$ of all conidiophores (Fig. 2B). Altogether, strawberry plant debris produced over $98 \%$ of the conidio-
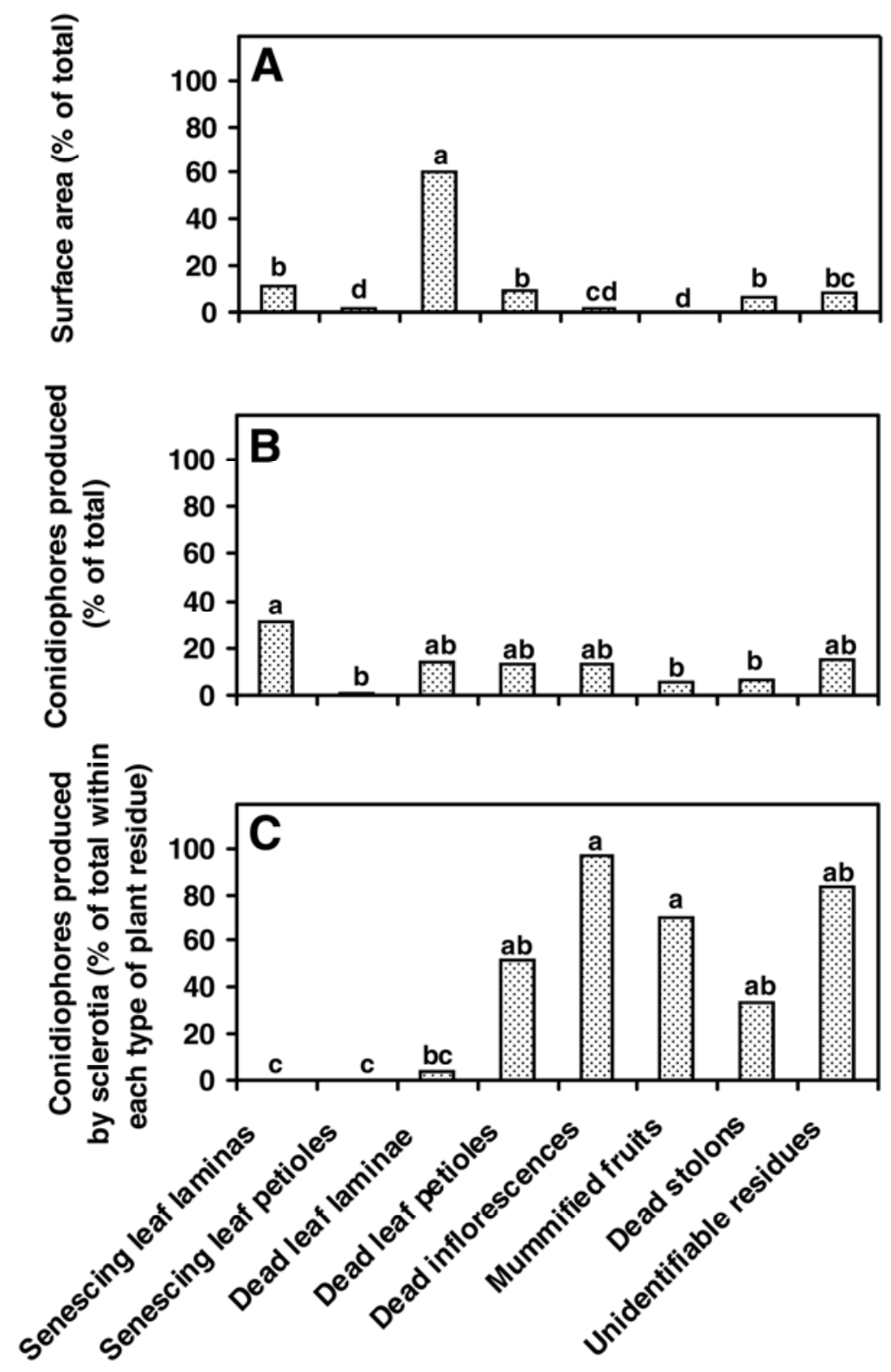

Fig. 2. A, Amount of different types of strawberry plant residue, as percentage of the total amount of plant residue, collected within planting beds; $\mathbf{B}$, number of conidiophores produced in different types of plant residue as percentage of the total production of conidiophores; and $\mathbf{C}$, percentage of conidiophores produced in each type of plant residue that originated from sclerotia. Values in all panels are nontransformed means of 13 samples collected from perennial strawberry fields in 2000 to 2002. Bars with different letters within each graph are significantly different $(P=0.05)$ according to Tukey's test applied to arcsine square root transformed data.

Table 2. Conidiophore and sclerotial populations of Botrytis cinerea in overwintered plant debris and soil collected prior to flowering from perennial strawberry fields in Norway

\begin{tabular}{|c|c|c|c|}
\hline Material & Conidiophores/m² & Sclerotia/m² & $\begin{array}{l}\text { Conidiophores originating } \\
\text { from sclerotia }(\%)\end{array}$ \\
\hline Plant debris from planting beds & 137,200 a $(18,700-652,400)$ & 1,165 a $(86-5,722)$ & 47 a (2-99) \\
\hline Plant debris from alleys & $2,900 \mathrm{~b}(0-11,300)$ & $18 \mathrm{c}(0-199)$ & 17 a $(0-99)^{z}$ \\
\hline Soil from planting beds and alleys & $2,000 \mathrm{~b}(0-10,500)$ & $63 \mathrm{~b}(0-188)$ & 57 a $(0-100)$ \\
\hline
\end{tabular}

y Nontransformed means of 13 samples collected from five counties in 2000 to 2002, along with minimum-maximum values in parentheses, are presented. Different letters within each column represent significant differences $(P=0.05)$ based on Tukey's test applied to log-transformed conidiophore and sclerotial counts and to arcsine square root transformed percentage data.

${ }^{\mathrm{z}}$ Mean and range were based on seven samples in which plant debris was present in alleys. 
phores while weeds produced the remainder (data not shown). Straw did not contribute to conidiophore production.

The amount of plant material collected from alleys was much smaller than that collected from planting beds (data not shown). Plant debris was found in only seven samples from alleys, largely because the alleys were kept clean of weeds and strawberry runner plants. The total surface area of plant material from alleys, excluding straw, varied from 0 to less than 2,000 $\mathrm{cm}^{2} / \mathrm{m}^{2}$ of alley. Almost $70 \%$ of this area was strawberry runner material while dead weeds (mainly grass species) constituted the rest. Strawberry material and dead weeds from samples collected from alleys yielded 80 and $20 \%$ of the conidiophores in the samples, respectively. Straw used as mulch was collected from fields in Vestfold and Rogaland but, for practical reasons, the surface area of the straw samples was not measured. Nevertheless, only four conidiophores of $B$. cinerea were detected in the straw altogether.

Importance of sclerotia in different plant residues. Sclerotia of $B$. cinerea were found in plant residues and soil (Table 2). The population of sclerotia in plant residues collected from planting beds ranged from less than 100 to more than $5,700 \mathrm{sclerotia} / \mathrm{m}^{2}$. The mean population in planting bed residue, 1,165 sclerotia $/ \mathrm{m}^{2}$, was significantly higher $(P<0.0001)$ than in plant residues from alleys and in soil. In some samples of alley debris and soil, no sclerotia were detected.

Conidiophores were produced directly from sclerotia in the collected samples. No apothecia were observed growing from sclerotia. There were no significant differences between planting bed residue, alley residue, and soil with respect to the mean contribution of sclerotia to the total conidiophore population (Table 2). Sclerotia yielded from 0 to over $99 \%$ of the total number of conidiophores counted within samples, and these numbers were not consistent over time in any particular field or consistent across fields in any particular year. For example, in Oppland, the total inoculum produced by sclerotia in the planting beds varied from 6 to $76 \%$ over 3 years and, in Rogaland, from less than 2 to
95\% between 2000 and 2001 in cv. Korona.

In plant debris collected from planting beds, sclerotia were found on dead strawberry material but not on senescing leaf laminae and petioles. Therefore, none of the conidiophores produced in the latter two categories originated from sclerotia (Fig. 2C). More than $90 \%$ of the conidiophores that came from sclerotia were found in dead stem residues (i.e., petioles, stolons, inflorescences, and unidentifiable stem parts; data not shown). Sclerotia were also abundant on mummified fruit; however, mummified fruit constituted only a very small fraction of the total surface area of plant residue (Fig. 2A). In dead leaf laminae, sclerotia played a minor role compared with mycelia in production of conidiophores (Fig. 2C).

Weather. Mean temperatures and accumulated precipitation for August through May in the years of investigation are shown in Table 3. In general, the lowest temperatures occurred in Oppland, which has a typical inland climate. Here, the mean temperature from August to May

Table 3. Monthly mean temperatures $\left({ }^{\circ} \mathrm{C}\right)$ and monthly accumulated precipitation $(\mathrm{mm})$ from August to May, measured at weather stations near the strawberry fields

\begin{tabular}{|c|c|c|c|c|c|c|c|c|c|c|}
\hline \multirow[b]{3}{*}{ Month } & \multicolumn{10}{|c|}{ Data from weather stations ${ }^{\mathrm{z}}$} \\
\hline & \multicolumn{2}{|c|}{ Oppland } & \multicolumn{2}{|c|}{ Vestfold } & \multicolumn{2}{|c|}{ Vest-Agder } & \multicolumn{2}{|c|}{ Rogaland } & \multicolumn{2}{|c|}{ Møre og Romsdal } \\
\hline & ${ }^{\circ} \mathbf{C}$ & $\mathbf{m m}$ & ${ }^{\circ} \mathbf{C}$ & $\mathbf{m m}$ & ${ }^{\circ} \mathbf{C}$ & $\mathbf{m m}$ & ${ }^{\circ} \mathbf{C}$ & $\mathbf{m m}$ & ${ }^{\circ} \mathbf{C}$ & $\mathbf{m m}$ \\
\hline \multicolumn{11}{|l|}{ 1999-2000 } \\
\hline August & 14 & 26 & 15 & 97 & 16 & 226 & 16 & 53 & 14 & 18 \\
\hline September & 13 & 111 & 14 & 164 & 14 & 213 & 16 & 106 & 16 & 30 \\
\hline October & 5 & 80 & 8 & 121 & 8 & 166 & 9 & 235 & 8 & 180 \\
\hline November & 3 & 26 & 5 & 46 & 6 & 87 & 6 & 243 & 7 & 201 \\
\hline December & -6 & 203 & -1 & 108 & 1 & 181 & 2 & 258 & 0 & 70 \\
\hline January & -2 & 16 & 1 & 36 & 2 & 119 & 4 & 209 & 2 & 330 \\
\hline February & -3 & 17 & 1 & 52 & 2 & 140 & 4 & 300 & 2 & 169 \\
\hline March & 0 & 20 & 2 & 23 & 3 & 53 & 3 & 185 & 2 & 172 \\
\hline April & 4 & 80 & 5 & 82 & 7 & 103 & 8 & 111 & 7 & 35 \\
\hline May & 12 & 42 & 11 & 107 & 12 & 166 & 12 & 116 & 11 & 37 \\
\hline Mean & 4 & 620 & 6 & 836 & 7 & 1,454 & 8 & 1815 & 7 & 1,241 \\
\hline \multicolumn{11}{|l|}{$2000-2001$} \\
\hline August & 14 & 50 & 15 & 83 & 15 & 86 & 14 & 215 & 13 & 121 \\
\hline September & 10 & 24 & 12 & 67 & 12 & 156 & 13 & 72 & 13 & 58 \\
\hline October & 8 & 168 & 10 & 237 & 10 & 256 & 11 & 189 & 11 & 13 \\
\hline November & 4 & 195 & 7 & 430 & 7 & 477 & 7 & 131 & 9 & 8 \\
\hline December & -1 & 51 & 2 & 114 & 3 & 187 & 4 & 28 & 4 & 38 \\
\hline January & -5 & 69 & -3 & - & 0 & 251 & 2 & 93 & 2 & 73 \\
\hline February & -8 & 29 & -4 & 141 & -2 & 28 & -1 & - & -2 & - \\
\hline March & -5 & 47 & -2 & 27 & -1 & 86 & 1 & 88 & 2 & 58 \\
\hline April & 3 & 50 & 4 & 49 & 4 & 137 & 5 & 48 & 6 & 58 \\
\hline May & 10 & 40 & 12 & 38 & 12 & 25 & 11 & 119 & 10 & 70 \\
\hline Mean & 3 & 722 & 5 & 1,186 & 6 & 1,688 & 7 & 983 & 7 & 499 \\
\hline \multicolumn{11}{|l|}{ 2001-2002 } \\
\hline August & 14 & 104 & $\ldots$ & $\ldots$ & $\ldots$ & $\ldots$ & 15 & 48 & $\ldots$ & $\ldots$ \\
\hline September & 10 & 77 & $\ldots$ & $\ldots$ & $\ldots$ & $\ldots$ & 12 & - & $\ldots$ & $\ldots$ \\
\hline October & 7 & 64 & $\cdots$ & $\cdots$ & $\cdots$ & $\cdots$ & 11 & - & $\begin{array}{l}\cdots \\
\cdots\end{array}$ & $\ldots$ \\
\hline November & 1 & 12 & $\ldots$ & $\ldots$ & $\ldots$ & $\ldots$ & 4 & _- & $\ldots$ & $\ldots$ \\
\hline December & -5 & 24 & $\begin{array}{l}\cdots \\
\cdots\end{array}$ & $\begin{array}{l}\cdots \\
\cdots\end{array}$ & $\begin{array}{l}\cdots \\
\cdots\end{array}$ & $\begin{array}{l}\cdots \\
\cdots\end{array}$ & 0 & - & $\begin{array}{l}\cdots \\
\cdots\end{array}$ & $\begin{array}{l}\cdots \\
\cdots\end{array}$ \\
\hline January & -7 & 62 & $\ldots$ & $\ldots$ & $\ldots$ & $\ldots$ & 3 & - & $\ldots$ & $\ldots$ \\
\hline February & -2 & 79 & $\ldots$ & $\ldots$ & $\ldots$ & $\ldots$ & 3 & 80 & $\ldots$ & $\ldots$ \\
\hline March & 0 & 26 & $\ldots$ & $\ldots$ & $\ldots$ & $\ldots$ & 3 & 90 & $\ldots$ & $\ldots$ \\
\hline April & 5 & 41 & $\ldots$ & $\ldots$ & $\ldots$ & $\ldots$ & 8 & 175 & $\ldots$ & $\ldots$ \\
\hline May & 11 & 80 & $\begin{array}{l}\cdots \\
\ldots\end{array}$ & $\begin{array}{l}\cdots \\
\ldots\end{array}$ & $\begin{array}{l}\cdots \\
\ldots\end{array}$ & $\begin{array}{l}\cdots \\
\ldots\end{array}$ & 12 & 184 & $\begin{array}{l}\cdots \\
\ldots\end{array}$ & $\begin{array}{l}\cdots \\
\ldots\end{array}$ \\
\hline Mean & 4 & 567 & $\ldots$ & $\ldots$ & $\ldots$ & $\ldots$ & 7 & - & $\ldots$ & $\ldots$ \\
\hline
\end{tabular}

${ }^{\mathrm{z}}$ Data collected from LMT weather stations (Bioforsk) at Apelsvoll (Østre Toten, Oppland County), Tjølling (Larvik, Vestfold County), Landvik (Grimstad, Vest-Agder county), Hjelmeland (Hjelmeland, Rogaland County), and Linge (Norddal, Møre og Romsdal county); - indicates missing data; ... in data fields for 2001-2002 indicates that these locations were not sampled. 
during the 3 years was 3 to $4^{\circ} \mathrm{C}$ whereas the mean temperature in Rogaland, with a coastal climate, was 7 to $8^{\circ} \mathrm{C}$ during the same period. Mean temperatures at other localities during the corresponding period ranged from 5 to $7^{\circ} \mathrm{C}$. The driest weather occurred at Oppland, where accumulated precipitation for August through May ranged from 500 to $700 \mathrm{~mm}$, whereas rainfall for the corresponding period at other localities ranged from 800 to $1800 \mathrm{~mm}$, with the exception of Møre og Romsdal in 2000 and 2001, where less than $500 \mathrm{~mm}$ of precipitation accumulated.

Multiple linear regressions were conducted to relate sclerotial data (sclerotial populations in the spring, percentages of conidiophores from sclerotia) to temperature, precipitation, or relative humidity occurring in the previous fall. No correlations were found.

\section{DISCUSSION}

Overwintering strawberry plant debris constituted by far the most important source of conidial inoculum of $B$. cinerea in the spring in perennial strawberry fields in Norway. Strawberry leaf laminae contributed a higher proportion of the overwintering plant debris than strawberry stem material but the two groups were equally important as sources of conidiophores. This result does not correspond to investigations in Ontario, where dead leaf laminae alone produced more than $80 \%$ of the conidiophores (2). In general, there was a higher potential inoculum level in the fields in our study compared with that reported from Ontario. We attempted to follow the procedures for sampling, incubation, and conidiophore counting described in the study from Ontario and, therefore, difference in conidiophore numbers was likely to be caused by factors other than methodology. The higher production of conidiophores in the present study than what was found in Ontario could be caused by more extensive colonization of plant parts by $B$. cinerea, which could be related to factors such as higher susceptibility of the strawberry cultivars or more humid conditions in the canopy. Also, differences in pathogen populations between Ontario and Norway could have influenced the results; strains of $B$. cinerea in strawberry fields in Norway may sporulate more readily than those in Ontario. It is known that different isolates of $B$. cinerea show different ability to sporulate in culture $(11,14)$.

We found that straw mulch was an insignificant inoculum source in strawberry in Norway, which agrees with findings in Ontario (2); however, in Scotland, Jarvis (10) observed that sclerotia of $B$. cinerea were commonly present on straw mulch in strawberry fields. These differences could be caused by use of straw from different cereal species: wheat straw was used in Norway and Ontario whereas barley is commonly used in Scotland, although straw type was not specified by the author (10). Weeds are potential inoculum sources of $B$. cinerea $(9,10,16)$ but good weed control minimized weeds as an inoculum source in this study. We observed abundant sporulation of $B$. cinerea from sclerotia and mycelium on overwintered, dead dicots (mainly thistle, Cirsium spp., and common hemp-nettle, Galeopsis tetrahit) adjacent to the fields (unpublished data), which suggests that inoculum from vegetation outside the fields might infect strawberry plants. However, the importance of inoculum production at the field borders was not investigated in this study.

As the plant material bearing sclerotia decompose, sclerotia released onto the ground may potentially serve as a source of inoculum. However, compared with strawberry plant residues in this study, soil was not an important substratum for production of conidiophores, perhaps due to a greater exposure to microbial degradation or growth-inhibiting chemical or physical components in the soil $(4,8,13)$.

We found that sclerotia on plant debris are important as an overwintering stage and as a site for sporulation. Sclerotia were the origin, on average, of approximately half of the conidiophores produced in plant debris. However, sample-to-sample variations were such that sclerotia predominated as the origin of conidiophores in some samples while mycelia appeared to predominate in others. Our results did not indicate that sclerotia consistently play a predominant role as an inoculum source in particular areas of the country or in particular fields from year to year. Environmental conditions probably influence sclerotial formation in the autumn $(5,14,20)$ but we did not find any correlation between temperature or humidity conditions occurring in the fall and the number of sclerotia present the following spring. Although a few reports on overwintering of $B$. cinerea in strawberry have been published, they included only one (10) or few (2) fields or years of investigation and, therefore, spatial and temporal variations with regard to sclerotia as source of inoculum in those regions may actually be greater than the reports indicated. In Ontario, sclerotia produced only 0.4 to $7 \%$ of the spring inoculum but it was found that most isolates of $B$. cinerea collected in the fields were able to produce sclerotia on agar media (2). In Scotland, sclerotia were assumed to be important for overwintering, because viable sclerotia were found abundantly on leaf petioles, stolons, inflorescence stems and peduncles, mummified strawberry fruit, straw fragments, and weeds; however, importance of sclerotia versus mycelia as source of conidiophores was not quantified (10).

There have been few reports on natural occurrence of apothecia of Botryotinia fuckeliana and, to our knowledge, the sex- ual stage of the fungus has never been observed in strawberry. It was suggested that the low numbers of sclerotia found in strawberry fields in Ontario contributed to the absence of apothecia (2). We did not observe apothecia of the fungus in our study, despite the abundance of sclerotia. Braun and Sutton (2) demonstrated, in laboratory experiments, that not all crosses of isolates resulted in apothecia formation, and lack of compatible mating types may explain why apothecia were not found in our investigations.

Control measures aimed at overwintering stages and sources of inoculum may reduce the need of fungicide applications during flowering and the risk of fungicide residues in ripe strawberry fruit $(1,12,21)$. The present investigation showed that, in Norway, overwintered strawberry plant residues are the most important sources of conidia in spring and, thus, control measures should be aimed at these materials. Control may be achieved by either suppressing the sporulation in the overwintering substrates or by removal of the substrates from the field. Sutton et al. (18) in Ontario found that machine harvesting of strawberry followed by removal of the cut foliage from the field reduced the gray mold epidemics by approximately $50 \%$ in the following year compared with hand harvesting, and concluded that this effect probably resulted from removal of the major overwintering substrate for the fungus. An additional advantage of removal of debris may be a reduced incidence of infection in developing and ripening fruit caused by contact between colonized organic material and healthy fruit (10). However, the results of our study suggest that removal of leaves alone post harvest or in the spring may not be completely effective in reducing spring inoculum; stem debris is as important as leaf debris for inoculum production, and it is probably more difficult to remove stem debris mechanically than leaves. Furthermore, sclerotia may fall off the debris in the process.

Because sclerotia can be a site for sporulation in the spring, they must be taken into account if fungicides or biocontrol agents are applied with the intent to reduce conidia production from overwintering structures. Both fungicides and biocontrol agents have been shown to suppress sporulation from mycelium in leaves $(1,12,19)$. However, laboratory experiments on naturally produced sclerotia indicated that sclerotia are more resistant than mycelia to fungicides and biocontrol treatments (G. M. Strømeng and A. Stensvand, unpublished data). Future work concerning integrated control of $B$. cinerea in perennial strawberry should explore the effect of both fungicides and biocontrol agents on viability of sclerotia and resting mycelium of the pathogen in overwintering strawberry plant debris. 


\section{ACKNOWLEDGMENTS}

Financial support was provided by Innovation Norway and the Research Council of Norway. We thank the growers T. Ids $\varnothing$, G. Bergaust, M. Sangnes, S. Haraldstad, and H. Gjedrem; the grower advisors J. K. Henriksen, K. Sola, N. E. Linge, and E. Stople; researchers A. Nes and V. Talgø for invaluable help during these investigations; D. M. Gadoury for critically reading the manuscript; and statistician T. Torp for advice on the statistical analyses.

\section{LITERATURE CITED}

1. Braun, P. G., and Sutton, J. C. 1986. Management of strawberry grey mould with fungicides targeted against inoculum in crop residues. Pages 915-921 in: Proc. Br. Crop Prot. Conf. Pests Dis.

2. Braun, P. G., and Sutton, J. C. 1987. Inoculum sources of Botrytis cinerea in fruit rot of strawberries in Ontario. Can. J. Plant Pathol. 9:1-5.

3. Braun, P. G., and Sutton, J. C. 1988. Infection cycles and population dynamics of Botrytis cinerea in strawberry leaves. Can. J. Plant Pathol. 10:133-141.

4. Coley-Smith, J. R. 1980. Sclerotia and other structures in survival. Pages 85-114 in: The Biology of Botrytis. J. R. Coley-Smith, K. Verhoeff, and W. R. Jarvis, eds. Academic Press Inc., London.
5. Ellerbrock, L. A., and Lorbeer, J. W. 1977. Survival of sclerotia and conidia of Botrytis squamosa. Phytopathology 67:219-225.

6. European Commission. 2006. Monitoring of pesticide residues in products of plant origin in the European Union, Norway, Iceland, Liechtenstein. Annual EU-wide Pesticide Residues Monitoring Report 2004. Online.

7. Groves, J. W., and Loveland, C. A. 1953. The connection between Botryotinia fuckeliana and Botrytis cinerea. Mycologia 45:415-425.

8. Harrison, J. G. 1979. Overwintering of Botrytis fabae. Trans. Br. Mycol. Soc. 72:389-394.

9. Jarvis, W. R. 1962. The epidemiology of Botrytis cinerea Pers. in strawberries. Pages 258-262 in: Proc. 16th Int. Hortic. Congress.

10. Jarvis, W. R. 1962. The infection of strawberry and raspberry fruits by Botrytis cinerea Fr. Ann. Appl. Biol. 50:569-575.

11. Jarvis, W. R. 1977. Botryotinia and Botrytis species: taxonomy, physiology, and pathogenicity. In: Monographs of the Canadian Department of Agriculture, Vol. 15. Ottawa, Canada.

12. Jordan, V. W. L., and Pappas, A. C. 1977. Inoculum suppression and control of strawberry Botrytis. Pages 341-348 in: Proc. Br. Crop Prot. Conf. Pests Dis.

13. Nair, N. G., and Nadtotchei, A. 1987. Sclerotia of Botrytis as a source of primary inoculum for bunch rot of grapes in New South Wales, Australia. J. Phytopathol. 119:42-51.

14. Paul, W. R. C. 1929. A comparative morphological and physiological study of a number of strains of Botrytis cinerea Pers. with special reference to their virulence. Trans. Br. Mycol Soc. 14:118-135.

15. Powelson, R. L. 1960. Initiation of strawberry fruit rot caused by Botrytis cinerea. Phytopathology 50:491-494.

16. Spotts, R. A., and Serdani, M. 2006. Inoculum sources of Botrytis cinerea important to pear orchards in Oregon. Plant Dis. 90:750-754.

17. Strømeng, G. M., and Stensvand, A. 2003 Overwintering of Botrytis cinerea in strawberry fields in Norway. IOBC wprs Bull. 26(2):181-186.

18. Sutton, J. C., James, T. D. W., and Dale, A. 1988. Harvesting and bedding practices in relation to grey mould of strawberries. Ann Appl. Biol. 113:167-175.

19. Sutton, J. C., and Peng, G. 1993. Biocontrol of Botrytis cinerea in strawberry leaves. Phytopathology 83:615-621

20. Townsend, B. B. 1957. Nutritional factors influencing the production of sclerotia by certain fungi. Ann. Bot. 21:153-166.

21. Xu, X., Harris, D. C., and Berrie, A. M. 2000 Modeling infection of strawberry flowers by Botrytis cinerea using field data. Phytopathology 90:1367-1374. 